profound knowledge of the classics. His garden, which furnished the rosebuds or sprigs of honeysuckle which he was wont to sport in his buttonhole, gave him much joy. For many years, too, he looked forward to his weekly round of golf. Happily he enjoyed good health until late in 1960, when, much to his regret, illness prevented his attendance at a gathering of former members of his Department, who had come from all over the country to do him honour.

Dr. Kenyon was married in 1917, and he is survived by his wife and only daughter. By his former undergraduate students he will be remembered as a careful and lucid lecturer, with a clear understanding of the problems which beset a student, but intolerant of slackness and slovenliness. His research students will recall his kindly and inspiring supervision of their work. Those who had the pleasure of serving on his staff will appreciate the encouragement he gave them in their research work, irrespective of the topics in which they were interested, and the manner in which he consulted them on all vital matters. All who knew him mourn the loss of a great chemist, of a great scholar, and, above all, of a great gentleman.

$$
\text { J. W. Sмгтн }
$$

\section{Prof. F. G. Gregory, F.R.S.}

WITH the death on November 27 of F. G. Gregory, plant science has lost one of its most dynamic twentieth-century personalities. Gregory was born on December 22, 1893, and attended the Dame Alice Owen School. From the time he left school until his retirement in 1958 - a period of forty-six years-he was associated with the Imperial College of Science and Technology (University of London). After graduating with first-class honours in botany, he joined the staff of the Research Institute of Plant Physiology, which was directed by Prof. V. H. Blackman. Later, he became assistant director of the Institute and eventually succeeded Blackman both as director and as professor of plant physiology in the Imperial College. He was elected a Fellow of the Royal Society in 1940, and a foreign member of the U.S. National Academy of Sciences in 1956. In 1957 he was awarded a Royal Medal of the Royal Society.

This, the bare outline of a highly successful academic career, gives little idea of the lifetime of high adventures of the mind which characterized it. Gregory had an unusual equipment in chemistry, physics and mathematics and as well an insatiable scientific curiosity. He brought his great breadth of knowledge to bear on a wide range of topics and illuminated them all. He began his researches at the time that the potential contribution of plant physiology to agriculture had been recognized by the establishment of the Research Institute under the auspices of the Ministry of Agriculture. Soon there began to appear in the Annals of Botany the series of papers which form a corner stone in the foundations of modern quantitative physiology. His name is especially linked with studies of methods of growth analysis, mineral nutrition and vernalization of cereals, and with important advisory work on cotton-growing in the Sudan. When the Agricultural Research Council took over responsibility for the Institute, Gregory served on many of its committees, but his primary interest remained always the daily events of the laboratory with which he never lost contact.
His published work records only part of his contribution to science; he will be remembered as much for his unique capacity to fire others with his own passion for inquiry. No one worked under Gregory, they worked with him; he was at their service to consider every notion with acumen and enthusiasm and to elicit from each one better than his best. His complex character with its often exaggerated response to events was capable as well of providing continuous encouragement and sympathy, and those who experienced his many kindnesses know how much time and trouble were spent in the consideration of their welfare. It was a source of deep satisfaction to him at the dinner given in his honour on retirement to see assembled so many of his former students and colleagues now themselves directing research.

His relaxations, pursued with equal fervour, were music (he was both a composer and an accomplished pianist) and philosophy. He was a voracious reader and had a considerable collection of books which he bequeathed to the Imperial College. He was un married.

Helen K. Porter

\section{Prof. C. H. O'Donoghue}

VIVID memories of zoology classes will have been recalled to many former students by the news of the death on November 28 of C. H. O'Donoghue, professor emeritus in the University of Reading, at the age of seventy-six. As a teacher he had the gift of presenting his material in a way made memorable by humour and of matching his subject with illuminating wit. To the many students who passed through his classes. either on the way to more advanced zoological studies or to medical or other scientific work, these are one of the more enduring memories of their undergraduate days. Though he often masked his serious purpose with a deliberately informal manner, O'Donoghue expected a high standard of work from his students and taught them to appreciate the impor. tance of the great general principles of zoology. These were usually in relation to comparative anatomy, which he clearly regarded as the most important ingredient of zoology as an educational subject. This does not mean, however, that he was not interested in other branches of the science, for he had a far-reaching knowledge of both marine and freshwater zoology, and an extraordinarily wide knowledge of animals of all sorts. He learned his zoology before the modern application of physics and chemistry to the study of animals and, though he appreciated the findings of this newer work, was never really at home in it.

As a research worker O'Donoghue made his reputa. tion first as an anatomist, and the series of papers on the vascular system of Sphenodon, Tropidonotus and Squalus are standard accounts. To this series also belongs the paper on abnormalities in the anuran vascular system which earned him the Neil Medal of the Royal Society of Edinburgh in 1932. In addition to this anatomical work on vertebrates, O'Donoghue also carried out taxonomic work on nudibranch molluses and bryozoans and is perhaps better known to more people as a specialist in one or other of these groups. It was mainly in Bryozoa that he had latterly interested himself, and he was still at work on collections of these animals up to the time of his death.

Charles Henry O'Donoghue was born in Bedford. shire in 1885 . He went to King's College, London, as 


\section{№. 4811 January 13,1962}

a student and in 1913 became an assistant in J. P. Hill's Department at University College, London. He left this in 1920 for the chair of zoology in the University of Manitoba, Winnipeg, returning to Great Britain on appointment to the Department of Natural History, University of Edinburgh, as lecturer in zoology and later reader and director of studies. He was appointed to the professorship of zoology in the University of Reading in 1939 and retired in 1952, when the title of emeritus professor was awarded to him. O'Donoghue had been particularly active in university affairs at Reading and in the years 1950-52 served as deputy vice-chancellor. He was invited to serve as first president of the Science Technologists' Association when it was formed in 1948 as a result of the great interest he had always shown in the welfare of laboratory technicians. He had acted as one of the secretaries of the Royal Society of Edinburgh (1937-39), president of the Royal Physical Society of Edinburgh (1933-36) and served on the Council of the Zoological Society of London.

He leaves a widow and son to whom every sympathy will be extended in their bereavement.

Alastair Grahain.

\section{NEWS and VIEWS}

\section{Contributions to Nature, 1961}

During the first year of the publication of Nature (November 1869-November 1870), the number of original communications (mainly "Letters to the Editor", together with some special articles, though not the general ones) was 378 . These came from 17 different countries. In certain selected years afterwards, the number of original communications were as follows (number of such countries in parentheses): $1910,285(19) ; 1920,422(17) ; 1930,568(27)$; $1937,648(31) ; 1949,1,066(35) ; 1958,2,362(59)$. During the past year (1961) the number of such communications ("Letters to the Editors" only) was 2,469 , and these were submitted from 65 different countries. These were distributed as follows:

Argentina
Australia
Austria
Belgium
Brazil
British Borneo
British East Africa
British Guiana
British Honduras
British West Africa
British West Indies
Canada
Ceylon
Chile
Congo
Czechoslovakia
Denmark
Fire
Egypt
Finland
France
French Central Africa
French West Africa
Gambia
Germany
Ghana
Greece
Holland
Hong Kong
Hungary
Iceland
Iran
Iraq
India
Israel

\begin{tabular}{|c|c|c|}
\hline 4 & Italy & 54 \\
\hline 150 & Japan & 87 \\
\hline 5 & Kenya & 8 \\
\hline 27 & Lebanon & 1. \\
\hline 10 & Malaya & 9 \\
\hline 1 & Mauritius & 1 \\
\hline 1 & New Guinea & 3 \\
\hline 2 & New Zealand & 34 \\
\hline 1 & Nigeria & 8 \\
\hline 1 & Norway & 17 \\
\hline 8 & Pakistan & 5 \\
\hline 105 & Philippines & 1 \\
\hline 1 & Yoland & 33 \\
\hline 3 & Portugal & 1 \\
\hline 4 & Puerto Rico & 3 \\
\hline 43 & Roumania & 5 \\
\hline 21 & Sarawak & 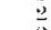 \\
\hline 12 & Sierra Leone & 2 \\
\hline 4 & South Africa & 27 \\
\hline 8 & Spain & 4 \\
\hline 30 & Sudan & 3 \\
\hline 1 & Sweden & 37 \\
\hline 1 & Switzerland & 9 \\
\hline i & Tanganyika & 3 \\
\hline 39 & Uganda & 7 \\
\hline 4 & United Kingdom & 794 \\
\hline 3 & United States & 593 \\
\hline 40 & Uruguay & 2 \\
\hline & U.S.S.R. (Russia) & 5 \\
\hline 32 & Venezuela & $\approx$ \\
\hline & Yugoslavia & 12 \\
\hline 1 & Total No. of countries & 66 \\
\hline $\begin{array}{r}104 \\
25\end{array}$ & $\begin{array}{l}\text { Total No, of communi- } \\
\text { cations }\end{array}$ & \\
\hline
\end{tabular}

These figures do not include research and other special articles, which have increased considerably over the past two years.

\section{Zoology at Oxford :}

Prof. J. W. S. Pringle, M.B.E., F.R.S.

THE appointment of Dr. J. W. S. Pringle, reader in experimental cytology in the University of Cambridge. to the Linacre professorship of zoology in the University of Oxford is important for the development of biology generally in Great Britain at the present time. Dr. Pringle's researches have been well known ever since his brilliant analysis of proprioception in insects ; and particularly through his demonstration of the 'gyroscopie' action of the halteres in Diptera, and the manner in which the necessary information for the control of flight could be gained by these flies through the 'strain-gauge' campaniform sensilla. He has also made major contributions to the comparative physiology of muscle, particularly by the brilliant interpretation of the mechanics of rapidly oscillating insect muscles which are used for flight or for the development of 'song' in the Cicadas.

Prof. Pringle's scientific interests have, however, not been restricted to these particular problems. He has made important contributions to our knowledge of the evolution of physiological systems in living organisms generally, and he has drawn important parallels between the development of behaviour in animals and their evolutionary history. $\mathrm{He}$ has also made contributions to the problems of the evolution of living systems from inanimate matter. While he was at Cambridge he not only undertook a very active programme in the teaching of undergraduates, particularly in the fields of cell biology and com. parative physiology, but also showed that he was a skilful man of affairs both in the administration of the Department of Zoology and while he held the office of bursar of his College (Peterhouse). He played a prominent part on the General Board of the Univer. sity which directs poliey. He finds in Oxford a school with many able workers, some of whom have interests closely related to his own, particularly Dr. John Baker. Biologists both here and overseas will wish him and the Department all success.

For a time, Sir Alister Hardy, until recently Linacre professor, will retain his title of professor and continue as head of the Department of Zoological Field Studies.

\section{Chelsea College of Science and Technology: \\ Dr. R. D. Purchon}

Prof. R. D. PURChON, at present professor of zoology in the University of Ghana, has been appointed head of the Department of Botany and Zoology in the Chelsea College of Science and Tech. nology in succession to Mr. C. C. Hentschel, who has become vice-principal of the College. Prof. Purchon is a graduate of the University of Bristol and recently received the degree of D.Sc. of that University. After teaching service in the University College of South Wales and Monmouthshire, Prof. Purchon became the first Raffles professor of zoology in the University of Malaya, Singapore, in 1950 . He was appointed professor of zoology in the University College of Ghana in January 1961. Prof. Purchon has done original zoological work in a number of fields, but he is chiefly known for his work on the anatomy and classification of marine Mollusca. 